\title{
Absence of abnormal erythrocyte superoxide dismutase, copper, or zinc levels in patients with retinitis pigmentosa
}

\author{
ROSALIE K. CROUCH AND JERRE K. CHAMBERS \\ From the Department of Ophthalmology, Storm Eye Institute, Medical University of South Carolina, \\ Charleston, South Carolina 29425, USA
}

SUMMARY Blood samples obtained from 22 patients with retinitis pigmentosa, 6 unaffected family members, and 8 unrelated controls showed serum copper and zinc to be in the normal range, contrary to the results in earlier reports. Likewise no significant variation of erythrocyte superoxide dismutase (SOD) and catalase levels was found between the 3 groups or when the patients were grouped by sex, age, or genetic distribution. The SOD proteins from controls and retinitis pigmentosa patients had identical mobilities on gel electrophoresis, isoelectric points, and heat stabilities. Our studies do not support the use of copper, zinc, or SOD in the diagnosis or treatment of retinitis pigmentosa.

Several studies have considered the connection between possible abnormalities in serum copper levels and the disease retinitis pigmentosa (RP). Gahlot et al. ${ }^{1}$ reported that for 15 patients serum copper levels were within a normal range but the plasma ceruloplasmin was decreased. In contrast Rao et al. ${ }^{2}$ reported an elevated serum copper level in a series of 24 patients with decreased ceruloplasmin levels. Bastek et al. ${ }^{3}$ also reported elevated copper levels in a family with X-linked RP. These results all imply an abnormal copper metabolism in RP patients. However, Ehlers and Bülow ${ }^{4}$ found normal values for both serum copper and plasma ceruloplasmin in a series of $11 \mathrm{RP}$ patients. Marmor et al. ${ }^{5}$ likewise found no abnormalities in serum copper, serum ceruloplasmin, and urinary copper excretion in 38 patients and 15 family members with recessive, dominant, and X-linked forms of RP.

About $60 \%$ of total red cell copper occurs incorporated in the enzyme superoxide dismutase (SOD, EC 1.15.1.1), ${ }^{6}$ which contains both copper and zinc. Copper is essential for the activity of the enzyme. ${ }^{7}$ Nutritional experiments in animals have confirmed that deficiency in copper can decrease the SOD activity in several tissues. ${ }^{8-10}$ In a person with copper deficiency the erythrocyte SOD is reported to be Correspondence to Dr Rosalie K. Crouch. decreased by about $50 \% .^{11}$ Furthermore, measurements with radioactive copper suggest that erythrocyte SOD obtains its copper from ceruloplasmin, indicating that a decrease in ceruloplasmin might affect SOD activity. ${ }^{12}$

The retina has been shown to contain several SOD isoenzymes, the major one being the same as the erythrocyte $\mathrm{Cu}-\mathrm{Zn}$ enzyme. ${ }^{13}$ SOD is part of the natural defence mechanism against oxygen damage and acts as a scavenger for the toxic superoxide radical. ${ }^{14}$ Any decrease in the level of this enzyme could result in the accumulation of the toxic superoxide radical which has been implicated in lipid peroxidation, sulphydryl group oxidation, and DNA damage.

The toxicity of the superoxide radicals can also be produced by their reaction with hydrogen peroxide, generating hydroxyl radicals which are highly reactive and affect most biological materials. ${ }^{\text {is }}$ The enzyme catalase inhibits this reaction by eliminating hydrogen peroxide. The damaging effects of a decreased SOD level might be overcome by an enhanced catalase content, and so this enzyme is also of interest. In view of the conflicting data on copper levels in RP patients and the biological importance of SOD we have compared the levels of copper, zinc, catalase, and SOD in the blood of RP patients, normal relatives, 
and controls. We have also studied the electrophoretic and heat sensitivity properties of the erythrocyte SOD in an attempt to detect any abnormalities in the enzyme obtained from RP patients.

\section{Materials and methods}

Venous blood was drawn from volunteer patients $(8$ males and 14 females between the ages of 14 and 66), 6 family members, and 8 healthy controls. Informed consent was obtained from each volunteer after the nature of the procedure had been explained. All the patients had been diagnosed as having RP by an ophthalmologist. A family history was taken from each patient. The majority of the patients had no family history of the disease, and these diseases were grouped as simplex. The disease in the remainder of the patients was found to be recessive, $\mathrm{X}$-linked, or dominant. Heparinised blood (1000 units $/ \mathrm{ml}$ ) was used for the haemoglobin, haematocrit, catalase, and SOD assays. Serum was used for the copper and zinc assays. Enzyme and haematocrit measurements were conducted on the same day the bloods were drawn, with control and test samples being processed simultaneously. The haemoglobin, copper, and zinc assays were performed on samples frozen at $-70^{\circ} \mathrm{C}$ for up to one week.

The haematocrit was measured with a Sedinak haemometer. The haemoglobin concentration was determined by Drabkin's reagent ${ }^{16}$ (Sigma). Catalase activity was measured colorimetrically with dichromate in acetic acid as described by Sinha. ${ }^{17}$ Activity of catalase is expressed as $\mu \mathrm{mol}$ hydrogen peroxide decomposed per min per $\mathrm{mg}$ of haemoglobin. The haemoglobin concentration was adjusted to $0.1 \mathrm{~g} / \mathrm{ml}$ and haemoglobin-free samples were prepared for the SOD assay as described by Winterbourn et al. ${ }^{18}$ The SOD activity was assayed by inhibition of nitroblue tetrazolium reduction by superoxide radicals generated by the xanthinexanthine-oxidase system. ${ }^{19}$ SOD activity is expressed as units/mg of haemoglobin where one unit (U) of activity is defined as the amount of enzyme activity which inhibits the rate of reduction of nitroblue tetrazolium by $50 \%$. It should be noted that the SOD activity values from different laboratories vary widely. The normal values obtained in this laboratory are in the range of $2 \cdot 0-3.5 \mathrm{U} / \mathrm{mg}$ haemoglobin, which agree with those of Winterbourn et al. ${ }^{18}$ Copper and zinc were determined by atomic absorption spectrometry. ${ }^{20}$ Triplicate measurements were obtained on each sample for all assays.

Data were treated statistically by Student's $t$ test. ${ }^{21}$ The variability of the data is presented as mean \pm SEM. Differences at $p<0.05$ were considered significant.
Disc electrophoresis was performed in $7.5 \%$ polyacrylamide gels with the system described by Maurer $^{22}$ except that stacking gels were not employed. Isoelectric focusing was performed in $7.5 \%$ polyacrylamide gels with a final concentration of $5 \%$ ampholytes $(\mathrm{v} / \mathrm{v})$ in the ranges of $\mathrm{pH} \mathrm{3.0-10}$ and $\mathrm{pH} 4-6 \cdot 5$ (Pharmacia Fine Chemicals). ${ }^{23}$ The potential was maintained at $200 \mathrm{~V}$ for $3.5 \mathrm{~h}$. After focusing a blank gel was sliced into sequential $5 \mathrm{~mm}$ sections. The sections were incubated overnight in 2 $\mathrm{ml}$ water and the $\mathrm{pH}$ determined. The gels were stained for SOD activity at $37^{\circ}$ for 1 hour as previously reported. ${ }^{13}$ Absence of dye uptake indicated reaction of the stain with the enzyme and presence of the enzyme. Duplicate gels were stained for protein with Coomassie brilliant blue according to the method of Weber and Osborn. ${ }^{24}$

Heat sensitivity was determined by heating a haemoglobin-free sample ${ }^{18}$ to a specific temperature and removing aliquots at certain time intervals. The aliquots were assayed immediately. The samples from control and RP patients were matched for age and sex.

\section{Results}

A comparison of copper, zinc, catalase, and SOD levels between 22 RP patients, 6 unaffected family members, and 8 unrelated controls showed all values to be within normal ranges. No significant differences were observed for any of metals or enzymes tested (Table 1). The haematocrits were determined and also found to be within the normal range of 36 to 52 for all 3 groups. The ages of the RP patients studied varied from 14 to 66 , but again when comparisons with controls were made by age and sex no significant differences were found (Fig. 1, Table 2).

Recessive, dominant, and X-linked forms of RP were represented in this study, but the majority of our patients had no family history of the disease (simplex). A similar genetic distribution has been

Table 1 SOD, catalase, copper, and zinc levels in RP patients, family members, and controls

\begin{tabular}{|c|c|c|c|c|}
\hline . & $\begin{array}{l}\mathrm{Cu} \\
\mu \mathrm{g} / 100 \mathrm{ml}\end{array}$ & $\begin{array}{l}\mathrm{Zn} \\
\mu \mathrm{g} / 100 \mathrm{ml}\end{array}$ & Catalase* & $\begin{array}{l}\text { SOD } \\
\text { U/mg H }\end{array}$ \\
\hline $\begin{array}{l}\text { RP patients } \\
(\mathrm{n}=22) \\
\text { Family members }\end{array}$ & $100 \pm 13$ & $104 \pm 15$ & $5.9 \pm 0.9$ & $2 \cdot 6 \pm 0 \cdot 7$ \\
\hline $\begin{array}{l}(n=6) \\
\text { Controls }\end{array}$ & $115 \pm 10$ & $102 \pm 6$ & $5 \cdot 1 \pm 1 \cdot 2$ & $3.4 \pm 0.8$ \\
\hline$(n=8)$ & $107 \pm 9$ & $108 \pm 9$ & $5 \cdot 8 \pm 1 \cdot 4$ & $3 \cdot 2 \pm 0 \cdot 7$ \\
\hline
\end{tabular}

* $\mu$ moles $\mathrm{H}_{2} \mathrm{O}_{2}$ decomposed per min per $\mathrm{mg} \mathrm{H}$.

$\mathrm{H}=$ Haemoglobin.

Each value given as the mean $\pm S E M$; for $n \geq 2$ the SEM is not applicable. 

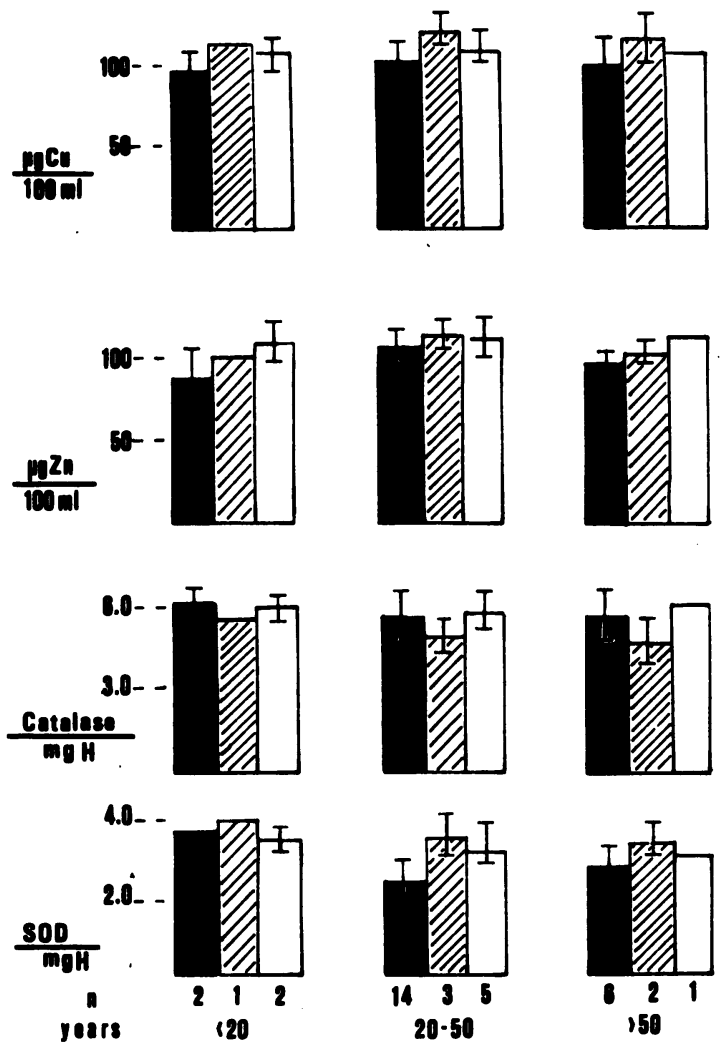

Fig. 1 Copper, zinc, SOD, and catalase levels compared by age: RP patients; 2070 unaffected family members; $\square$ unrelated controls. Brackets represent $S E M ; n=$ number of samples in group; $H=$ haemoglobin.

Table 2 Male and female: copper, zinc, SOD, and catalase levels

\begin{tabular}{|c|c|c|c|c|c|c|}
\hline Group & Sex & $n$ & $\begin{array}{l}\mathrm{Cu} \\
\mu \mathrm{g} / 100 \\
\mathrm{ml}\end{array}$ & $\begin{array}{l}Z n \\
\mu g / 100 \\
m l\end{array}$ & se* & $\begin{array}{l}S O D \\
\text { U/mg } H\end{array}$ \\
\hline $\begin{array}{l}\text { RP } \\
\text { patients } \\
\text { Family } \\
\text { members } \\
\text { Controls }\end{array}$ & $\begin{array}{l}\text { Male } \\
\text { Female } \\
\text { Male } \\
\text { Female } \\
\text { Male } \\
\text { Female }\end{array}$ & $\begin{array}{r}8 \\
14 \\
1 \\
5 \\
4 \\
4\end{array}$ & $\begin{array}{l}107 \pm 15 \\
94 \pm 13 \\
120 \\
112 \pm 8 \\
110 \pm 10 \\
104 \pm 7\end{array}$ & $\begin{array}{c}108 \pm 15 \\
95 \pm 10 \\
110 \\
98 \pm 1 \\
112 \pm 10 \\
103 \pm 12\end{array}$ & $\begin{array}{l}6 \cdot 1 \pm 0.4 \\
5 \cdot 6 \pm 0.8 \\
5 \cdot 4 \\
5 \cdot 0 \pm 1 \cdot 0 \\
5.5 \pm 1.0 \\
6 \cdot 2 \pm 0.9\end{array}$ & $\begin{array}{l}2 \cdot 5 \pm 0.6 \\
3 \cdot 6 \\
3 \cdot 3 \pm 0.5 \\
2 \cdot 8 \pm 0.8 \\
3 \cdot 3 \pm 0.9\end{array}$ \\
\hline
\end{tabular}

* $\mu$ moles $\mathrm{H}_{2} \mathrm{O}_{2}$ decomposed per min per $\mathrm{mg} \mathrm{H}$.

$\mathrm{H}=$ Haemoglobin.

Each value is the mean $\pm S E M$; for $n \geq 2$ the SEM is not applicable.

reported by Berson et al. ${ }^{25}$ From family history the RP patients were grouped as shown in Table 3, and again there was no significant variation of SOD levels.

The erythrocyte SOD enzymes were examined by
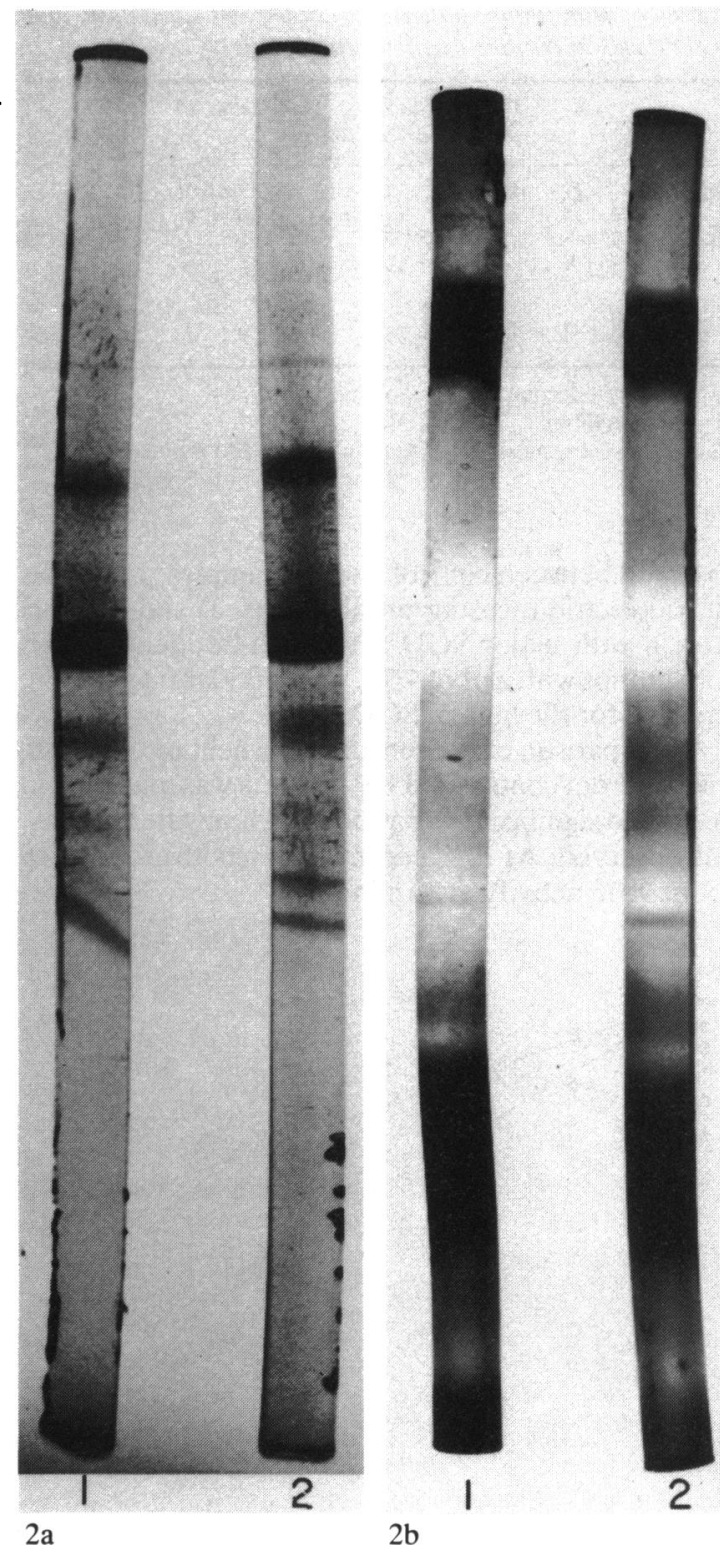

Fig. 2 Polyacrylamide gel isoelectrophoric focusing patterns. Normal and RP haemolysates: (a) Gels stained for protein: 1-RP; 2-control. (b) Gels stained for SOD activity: 1-RP;2-control; absence of stain indicated SOD activity. The $\mathrm{pH}$ range of the ampholytes was 3-10.

gel electrophoresis to determine if there were any major differences between controls and RP patients in the enzyme molecular weight or charge distribution. On 7.5\% polyacrylamide gels stained for both protein and SOD activity no differences were 
Table 3 Inheritance patterns of copper, zinc, catalase, and $S O D$ levels in retinitis pigmentosa patients

\begin{tabular}{|c|c|c|c|c|c|}
\hline & $n$ & $\begin{array}{l}\mathrm{Cu} \\
\mu \mathrm{g} / 100 \mathrm{ml}\end{array}$ & $\begin{array}{l}\mathrm{Zn} \\
\mu \mathrm{g} / 100 \mathrm{ml}\end{array}$ & Catalase* $^{*}$ & $\begin{array}{l}\text { SOD } \\
U / m g H\end{array}$ \\
\hline Simplex & 12 & $104 \pm 10$ & $106 \pm 12$ & $5 \cdot 7 \pm 1 \cdot 0$ & $2 \cdot 8 \pm 0 \cdot 5$ \\
\hline Recessive & 7 & $98 \pm 11$ & $101 \pm 5$ & $6.0 \pm 0.5$ & $2.9 \pm 0.9$ \\
\hline Dominant & 2 & 103 & 98 & $5 \cdot 5$ & $2 \cdot 2$ \\
\hline $\begin{array}{l}\text { X-linked } \\
\text { Female }\end{array}$ & 1 & 92 & 105 & $5 \cdot 5$ & $2 \cdot 6$ \\
\hline carrier & 1 & 115 & 104 & $5 \cdot 9$ & $3 \cdot 0$ \\
\hline
\end{tabular}

${ }^{*} \mu$ moles $\mathrm{H}_{2} \mathrm{O}_{2}$ decomposed per min per $\mathrm{mg} \mathrm{H}$.

$\mathrm{H}=$ Haemoglobin.

Each value is the mean $\pm S E M$; for $n \geq 2$ the SEM is not applicable.

observed between control and RP samples. Likewise the isoelectric focusing profiles (Fig. 2) showed the protein with major SOD activity to be identical for both groups with a pI of $4 \cdot 75$, which is identical to that reported for the human SOD. ${ }^{26}$

A comparison of the sensitivity to heat of the SOD enzyme from control and RP patients was made (Fig. 3 ), and no significant variation in the enzyme stability was observed. At $72^{\circ} \mathrm{C}$ enzymes from both groups lost about $90 \%$ activity in 20 minutes.

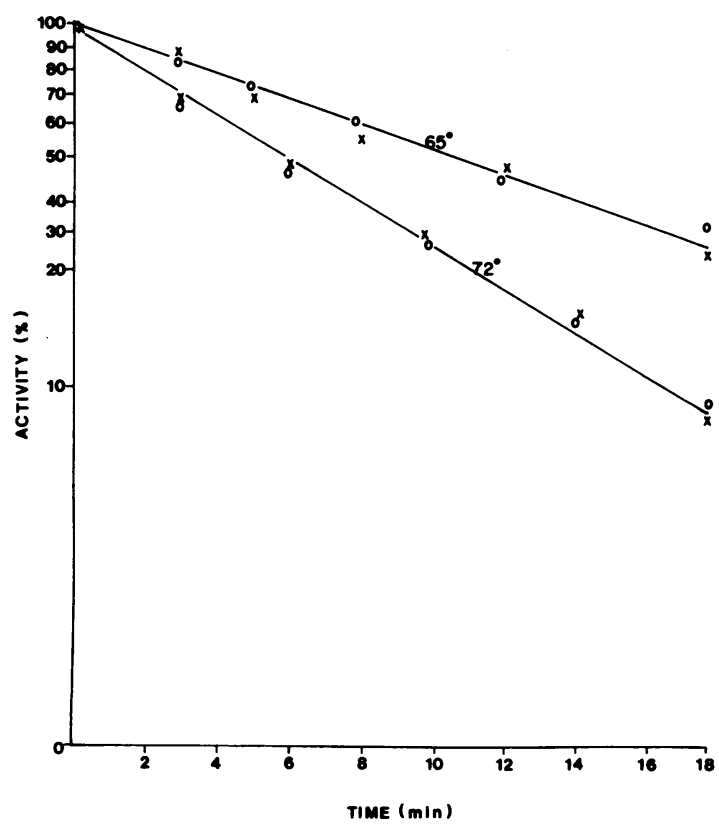

Fig. 3 Temperature inactivation of enzymes from $R P$ patients and controls. Haemoglobin-free enzyme solutions were subjected to heat at $65^{\circ} \mathrm{C}$ and $72^{\circ} \mathrm{C}$. Aliquots were withdrawn at times indicated and the activities assayed. $\mathrm{O}-\mathrm{O}$ controls; $\mathrm{X}-\mathrm{X} R P$ samples.

\section{Discussion}

Abnormalities in both copper and zinc levels have been reported in patients with RP. ${ }^{12}$ As the major erythrocyte and retinal SOD enzyme contains both copper and zinc, and as copper deficiency has been linked to a SOD decrease, it seems logical that there might be an abnormal level of this enzyme in RP patients. However, the results of this study did not support these earlier reports of abnormal copper or zinc levels in RP patients. The data were grouped according to age, sex, and inheritance patterns, but no significant variation was detected in any of these classifications. Particular attention was paid to the one case of X-linked RP which we had in the study, but contrary to the report by Bastek et al. ${ }^{2}$ we did not find elevated copper levels in this patient or the carrier, nor did we find a higher level of zinc in this female carrier. Therefore from our data, and in agreement with the studies of Marmor et al. ${ }^{5}$ and Ehlers and Bülow, ${ }^{4}$ we found no evidence of abnormal copper and zinc metabolism in RP patients, at least in this patient population.

As the copper and zinc levels appear to be normal in RP patients, it is not surprising that we did not detect any abnormalities in SOD levels. Additional evidence that there are no alterations in the SOD enzyme itself is gained from the electrophoretic and heat stability properties of enzymes from control and RP patients. The identical gel patterns of the samples show that the molecular weight and charge distribution are the same for the enzymes. A decrease in the heat stability of several enzymes including SOD $^{27}$ with age has been observed. However, in samples taken from controls and RP patients of similar age and sex the sensitivity to heat was the same, and thus there is no premature 'aging' or inactivation of the enzyme. Likewise we observed no major abnormalities in catalase levels. It should be noted that the derivations of the catalase measurements are high and only major differences would be noted. Thus the erythrocyte levels of these enzymes protecting against oxygen toxicity are within the normal range for patients with RP.

The reasons for the discrepancies between our results on copper and zinc levels and those of earlier reports ${ }^{13}$ remain to be explained and may be due to differences in patient population. However, our studies do not support the use of copper, zinc, or SOD in the diagnosis or treatment of RP.

We thank Dr R. Gadsen, Department of Laboratory Medicine, for the assays of copper and zinc, and Michael Redmond for the isoelectric focusing studies. The help of Dr B. Thompson and Roberta Kimsey in collecting blood and the excellent technical assistance of Gary Kimsey are appreciated. The statistical analysis was performed by Mark E. Lacy. Partial support for this study was provided by the State of South Carolina Appropriation for Research. 


\section{References}

1 Gahlot DK, Khosla PK, Makashir PD, Vasuki K, Basu N. Copper metabolism in retinitis pigmentosa. $\mathrm{Br} J$ Ophthalmol 1976; 60: 770-4.

2 Rao SS, Satapathy M, Sitaramayya A. Copper metabolism in retinitis pigmentosa patients. Br J Ophthalmol 1981; 65: 127-30.

3 Bastek J, Bogden J, Cinotti A, et al. Trace metals in a family with sex-linked retinitis pigmentosa. In: Landers MB, Wolbarsht ML, Dowling JE, Laties AM, eds. Retinitis Pigmentosa-Clinical Implications of Current Research. New York: Plenum Press, 1977; 43-50.

4 Ehlers N, Bülow N. Clinical copper metabolism parameters in patients with retinitis pigmentosa and other tapeto-retinal degenerations. Br J Ophthalmol 1977; 61: 595-6.

5 Marmor MF, Nelson JW, Levin AS. Copper metabolism in American retinitis pigmentosa patients. Br J Ophthalmol 1978 62: 168-71.

6 Underwood EJ. Trace Elements in Human and Animal Nutrition. New York: Academic Press, 1977; 56-108.

7 Heikkila RE, Cabbat FS, Cohen G. In vivo inhibition of superoxide dismutase in mice by diethyedithiocarbamate. J Biol Chem 1976; 25: 2182-5.

8 Williams DM, Lynch RE, Lee GR, Cartwright GE. Superoxide dismutase activity in copper-deficient swine. Proc Soc Exp Biol Med 1975; 149: 534-6.

9 Okonkwo AC, Ku PK, Miller ER, Keahey KK, Ullrey DE. Copper requirement of baby pigs fed purified diets. J Nutr 1979 109: 939-48.

10 Paynter DI, Moir RJ, Underwood EJ. Changes in activity of the $\mathrm{Cu}-\mathrm{Zn}$ superoxide dismutase enzyme in tissue of the rat with changes in dietary copper. J Nutr 1979; 109: 1570-6.

11 Okhata S, Nishi Y, Hatano S, Kobayashi Y, Usui T. Changes in erythrocyte superoxide dismutase in a patient with copper deficiency. Eur J Pediatr 1980; 134: 121-4.

12 Marceau N, Aspin N. The association of the copper derived from ceruloplasmin with cytocuprein. Biochem Biophys Acta 1973; 328: 351-8.
13 Crouch R, Priest DG, Duke EJ. Superoxide dismutase activities of bovine ocular tissues. Exp Eye Res 1978; 27: 503-9.

14 Fridovich I. The biology of oxygen radicals. Science 1978; 201: 875-80.

15 Halliwell B. Biochemical mechanisms accounting for the toxic action of oxygen on living organisms: the key role of superoxide dismutase. Cell Biol Int Rep 1978; 2: 113-28.

16 Drabkin DL, Austin JH. Spectrophotometric studies. II. Preparations from washed blood cells; nitric oxide hemoglobin and sulfhemoglobin. J Biol Chem 1935; 112: 51-65.

17 Sinha AK. Colorimetric assay of catalase. Anal Biochem 1972; 47: 389-94.

18 Winterbourn CC, Hawkins RE, Brian M, Carrell RW. The estimation of red cell superoxide dismutase activity. $J$ Lab Clin Med 1975; 85: 337-41.

19 Beauchamp C, Fridovich I. Superoxide dismutase: improved assays and an assay applicable to acrylamide gels. Anal Biochem 1971; 44: 276-87.

20 Parker MM, Humoller F, Mahler DJ. Determination of copper and zinc in biological material. Clin Chem 1967; 13: 40-8.

21 Steel RGD, Torrie JH. Principles and Procedures of Statistics. New York: McGraw Hill, 1960.

22 Maurer HR. Disc Electrophoresis and Related Techniques of Polyacrylamide Gel Electrophoresis. New York: Walter deGruyter, 1971: 32-110.

23 Righetti PG, Drysdale JW. Laboratory techniques in biochemistry and molecular biology. Isoelectric Focusing. Amsterdam: North Holland, 1976: 5: part 2.

24 Weber K, Osborn M. The reliability of molecular weight determinations by dodecyl sulfate-polyacrylamide gel electrophoresis. $J$ Biol Chem 1969; 244: 4406-12.

25 Berson EL, Rosner B, Simonoff E. Risk factors for genetic typing and detection in retinitis pigmentosa. Am J Ophthalmol 1980;89: 763-75.

26 Hartz JW, Deutsch HF. Preparation and physicochemical properties of human erythrocuprein. J Biol Chem 1969; 244: 4565-72.

27 Reiss U, Gershon D. Rat-liver superoxide dismutase Purification and age-related modifications. Eur J Biochem 1976; 63: 617-23. 